\title{
Causes of Delays in any Construction Project
}

\author{
Naikwadi Sumaiyya R. ${ }^{1}$, Khare Pranay $\mathbf{R}^{2}$ \\ ${ }^{1}$ P.G. Student, ME Civil (Construction \& Management), Dr. D. Y. Patil School of Engineering \& Technology, \\ Charholi - Pune, Maharashtra/India \\ Savitribai Phule Pune University \\ ${ }^{2}$ Assistant Professor Dept. of Civil Engineering, Dr. D. Y. Patil School of Engineering \& Technology, \\ Charholi -Pune/Pune, Maharashtra/India \\ Savitribai Phule Pune University
}

\begin{abstract}
Construction industry is one of fast growing industry all over the world Delays are one of the biggest problem in construction project. Construction delays can be identified as late completion of construction project. Delays can be minimized only when their causes are indentified. The objective of this paper is to study causes of construction delays, effects of delays and methods of minimizing construction delays. Project delay basis of Past literature review. There are many factors induced in delay of project some of factors identified as: lack of funds, changes in drawing, lack of effective communication, poor project management. It is therefore recommended that adequate construction budget, timely issuing drawings and information, good project management skills should be main focus of project procurement process.
\end{abstract}

Keywords: causes of delays, effects of delays, construction project, project management

\section{Introduction}

Construction industry are one of growing industry in all over world. In construction projects time and cost overruns are identified as one of most important factors responsible for abandonment. Delays and disruptions are challenges faced by construction industry. The purpose of this study is to review past studies on determining the factors which are responsible for delays.

In most countries biggest client is government. (Okpala and Aiekwu), to dislike of private industry, many government project experience delay and so exceeds initial time and cost estimates(odeh sand bataineh). Indian construction industry has gained far more importance in recent times because of opening up of Indian markets and the arrival of mega projects for infrastructure development the performance of Indian construction projects. A study conducted by infrastructure and project monitoring division of ministry of statistics and program implementation (http://www.mospi.nic.in) reports that oput of 646 central sector projects (which are of order of more than $\$ 4.45$ million ) costing around $\$ 50$ trillion and average project duration of six to seven years, about $40 \%$ are behind schedule and delay ranges 1 to 252 months the schedule overrun in \% terms as on December 2003 was reported to be $40.23 \%$ while figure for the same as on December 2004 was to be $39.9 \%($ K. C Iyer and K. N. Jha, 2006).

It is seen from previous studies(Abd Majid and Mccraffer, 1998), Alwi and hampson(2003), Assaf and Al-Hejji(2006) that the failure of project is mainly related to performance of project which causes delay or overrun.

\section{Literature Review}

Many research articles are published so for to study delays in construction. Findings of such research have been used for this research.
In the study of Alaghbari et al.(2007),Delay is generally acknowledged as the most common, costly, complex and risky problem encountered in construction projects, Because of the high importance of time for both the owner and contractor, it is source of continuous disputes and claims leading to law-suits.

N.Hamezah, M.A.Khoiry, I.Arshad, N.M.Tawil and A.I.Che Ani(2011) "Causes of construction Delay,Theoretical framework" In this paper the framework are develop by three different author. The result of his study as follows :Financial difficulties and economic problem ,financial problems, supervision to late and slowest in making decision ,lack of materials on markets, poor site management, construction mistakes and defective work

Alwi Keith(2003) found causes of delay in construction project in Indonesia. Questionnaire survey was carried out targeting 89 respondents from large contractor and 23 respondents from small contractor. Respondents were asked to access the level of effect 31 potential delay causes on their projects. The delay factor group into six major groups, Result shows that there is no agreement between two groups of contractor. The professional management group was ranked the highest and the external group was ranked by the small contractor, whereas the small contractors ranked the design documentations group as highest and the execution group as lowest.

Doloi H. et al (2012) did research on Indian construction projects. A questionnaire and personal interview have form the basis of their research. Factor analysis and regression 2 modeling were used to examined the significance of their factors. From factor analysis most critical factor of construction delays are lack of commitment insufficient site management and site coordination ranked third. 


\section{Objectives}

In present scenario of construction world, though we have lot of methods for timely completion of projects, still delay is inevitable, which ultimately affect the efficiency of project.

Perhaps lot of studies carried out for delay findings and minimizing ill effects of delays in projects. Still there are lot of projects which run behind schedule and suffers heavy loss

Construction is ever changing challenging and dynamic industry. The research is aimed to indentify major causes of delay. To achieve aims, are identified as follows:

- To indentify reasons of delay

- To indentify effects of delay

- To indentify methods of minimizing delay

\section{Methodology}

- Literature Collection

- Review of Literature

- Factors Identification

- Data Collection

- Analysis of Data

\section{Types of Delays}

According to Menesi (2007), delays are classified into two different types to liability:

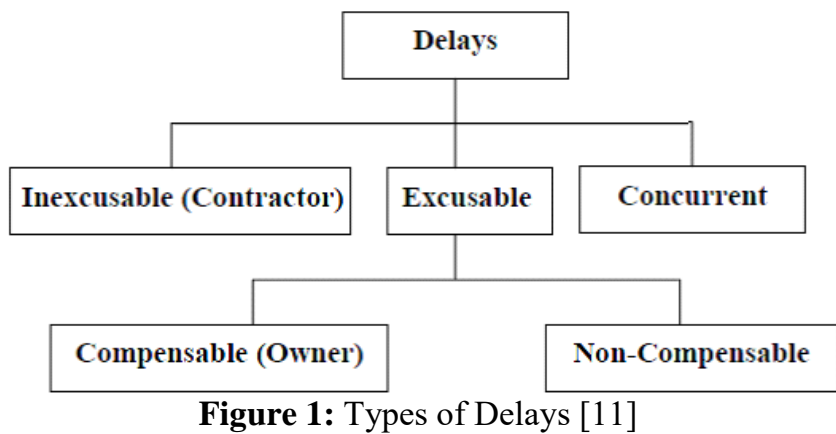

Delays that affect completion time are known as critical delays and which do not affect project completion time which mentioned in contract are known as non critical delays.

Excusable delay is unforeseen activity which is beyond control of contractor. In this type of delays nobody is liable for penalty.

Non-excusable delays (NED)are within control of contractor and Non excusable delays are responsibility of contractor and client may be entitled for the compensation

Excusable delay can only be compensable delay. A compensable is delay in which contractor is entitled to additional time and compensation. Under non compensation delay the contractor is not entitled to any compensation resulting from the excusable delay[10]
When Same delays repeated, impacted the project critical activity, is known as concurrent delay.

\section{Data Analysis}

For Data analysis various researches use RII (Relative Importance Index) to determine importance of various causes of delay.

The program implementation division of MOSPI (India) publishes flash reports on mega projects having information of central sector infrastructure project costing rupees 1000 crores and above (Ashwini Arun Salunkhe and Rahul S. Patil).Each Report contains information of all ongoing, completed as well as delayed projects for receptive months

According to MOSPI data (2004),Out of 568 projects, 31 Projects are ahead of schedule ,152 are on schedule, 211 projects are delayed with respect to the original schedule, For 149 projects ,the date commissioning is not available and for 25 projects, date of commissioning has not be firmed up. And analysis of time and cost overrun of all the 568 projects with respect to the original approved schedule.

\section{Conclusion}

Study concludes that there exist various factors affecting completion time of project and their effects put construction projects at high risk that have effect on their performance. These causes are: delays in payment to contractor, information delays, poor project management, compensation issues, design changes, whether effects, labor strikes. Effects of these delays are cost overruns, time overruns, disputes and negative social impact.

\section{Recommendations for Future Work}

More research on construction delays should be done in order to minimize the ill effects of delays in construction projects.In order to provide more reliable data, more specific studies should be conducted in various fields including Highways, Dams, and Industrial Projects. Also detailed study on cash flow and budget should be done.

It is recommended that adequate budget, finalizing design timely issuing of information, project management skills should of main importance while procurement of project.

\section{Acknowledgment}

I express my deepest gratitude to my project guide Prof. Pranay R. Khare, whose encouragement, guidance and support me to develop an understanding of the subject.

Dr. Sanjay K. kulkarni Head of the Civil Engineering Department, Dr. D.Y.Patil School of Engineering \& Technology for providing their invaluable advice and for providing me with an environment to my project successfully.

Finally, I take this opportunity to extend my deep appreciation to my family and friends, for all that they meant to me during the crucial times of my project. 


\section{References}

[1] K.C.Iyer and K.N.Jha (2006) "Critical Factors Affecting Schedule Performance: Evidence from Indian Construction Projects",Journal of Construction Engineering and Management ,Vol.132,No.8,Page No.871-881.

[2] Abd.Majid,M.Z,and McCraffer,R. (1998). "Factors of non-excusable delays that influence contractor"ecs performance".J.Mange.Eng., 14(3),42-49.

[3] Alwi,S.,and Hampson,K.(2003). "Identifying the important causes of delays in building construction projects".The $9^{\text {th }}$ East Asia-Pacific conference on structural eng. and constr.,Bali,Indonesia.

[4] Asaf,S.A., and Al-hejji S. (2006). "Causes of delay in large construction projects". International J. Project Mgmt.,Science Direct, 24,349-357.4.

[5] Okpala, D.C. and Aiekwu, A.N. (1988) „Causes of high costs of construction in Nigeria ${ }^{\text {ee, Journal of }}$ Construction Engineering and Management, 114 (2), 233-244.

[6] Odeh A.M. and Battaineh, H.T. (2002) "Causes of Construction delay:traditional contracts", International Journal of Project Management,20,67-73.

[7] Hamzah,N.,Khoitry, M.A.,Arshad,I.,Tawil,N.M.,and Che Ani, A.I. (2011), “ Causes of construction delay theoretical framework". Procedia Eng.,Science Direct,20,490-495.

[8] Alaghbari, W., Kadir, M.R.A., Salim, A. and Ernawati (2007) "The Significant Factors causing delay of building construction projects in Malaysia. Engineering", Construction and Architectural Management Journal, 14(2),192-206.

[9] Doloi H., Sawhney A., Iyer K.C. and Rentala S.(2012) "Analysing factors affecting delays in Indian construction projects", International journel of /project Management, Volume 30, Issue 4, Pages 479-489.

[10] Ashwini Arun Salunkhe and Rahul S. Patil .(2014) Effect Of Construction Delays On Project Time Overrun:Indian Scenerio", International Journal of research in Engineering and Technology, Volume 03, Issue 01, Pages 544-545

[11] Menesi W.(2007)."Construction delay analysis under multiple baseline updates". A Thesis Report. 